\title{
Fear of falling in older adults living at home: associated factors*
}

\author{
Medo de cair em idosos residentes no domicílio: fatores associados \\ Miedo de caer en ancianos residentes en su domicilio: factores asociados
}

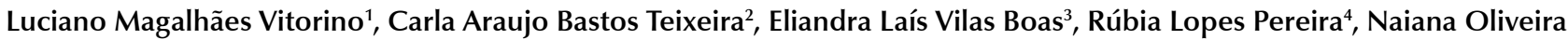
dos Santos ${ }^{5}$, Célia Alves Rozendo ${ }^{6}$

How to cite this article:

Vitorino LM, Teixeira CAB, Vilas Boas EL, Pereira RL, Santos NO, Rozendo CA. Fear of falling in older adults living at home: associated factors. Rev Esc Enferm USP. 2017;51:e03215. DOI: http://dx.doi.org/10.1590/S1980-220X2016011803215

* Extracted from the project "Avaliação da preocupação dos idosos da comunidade em cair”, Escola de Enfermagem Wenceslau Braz, 2012.

${ }^{1}$ Universidade Federal de São Paulo, Escola Paulista de Enfermagem, São Paulo, SP, Brazil.

${ }^{2}$ Universidade de São Paulo, Escola de Enfermagem de Ribeirão, Programa de Pós-Graduação em Enfermagem Psiquiátrica, Ribeirão Preto, SP, Brazil.

${ }^{3}$ Escola de Enfermagem Wenceslau

Braz, Itajubá, MG, Brazil.

${ }^{4}$ Hospital Escola de Itajubá, Itajubá, MG, Brazil.

${ }^{5}$ Universidade Federal do Rio Grande do Sul, Escola de Enfermagem, Porto Alegre, RS, Brazil.

${ }^{6}$ Universidade Federal de Alagoas, Escola de Enfermagem e Farmácia, Maceió, AL, Brazil.

\section{ABSTRACT}

Objective: To identify the factors associated with the fear of falling in the older adult living at home. Method: Cross-sectional study with probabilistic sampling of older adult enrolled in two Family Health Strategies (FHS). The fear of falling was measured by the Brazilian version of the Falls Efficacy Scale-International and by a household questionnaire that contained the explanatory variables. Multiple Linear Regression using the stepwise selection technique and the Generalized Linear Models were used in the statistical analyses. Results: A total of 170 older adults participated in the research, 85 from each FHS. The majority (57.1\%) aged between 60 and $69 ; 67.6 \%$ were female; $46.1 \%$ fell once in the last year. The majority of the older adults $(66.5 \%)$ had high fear of falling. In the final multiple linear regression model, it was identified that a higher number of previous falls, female gender, older age, and worse health self-assessment explained $37 \%$ of the fear of falling among the older adult. Conclusion: The findings reinforce the need to assess the fear of falling among the older adult living at home, in conjunction with the development and use of strategies based on modifiable factors by professionals to reduce falls and improve health status, which may contribute to the reduction of the fear of falling among the older adult.

\section{DESCRIPTORS}

Aged; Accidental Falls; Fear; Geriatric Nursing; Family Health Strategy; Cross-Sectional Studies. 


\section{INTRODUCTION}

Falls are defined as events in which the individual inadvertently comes to rest on the ground or lower level, against his will. This event has a high incidence among people over 65 years old, reaching $30 \%$ of the older adult living at home. Falling is considered one of the most common causes of hospitalization in the older adult population ${ }^{(1)}$. It is estimated that one in three older adult people suffers a fall yearly and less than half report it to their physicians. Among these falls, one in five causes serious injury, such as fractures or head injuries ${ }^{(2)}$, which implies in a high impact on health care expenses worldwide ${ }^{(1,3)}$ and contributes to the fact that falls among the older adult are a public health issue ${ }^{(4)}$.

Besides the fall itself, an important aspect to be emphasized in the older adult population is the fear of falling, which has been described as a permanent fear or worry of tumbling ${ }^{(3)}$. This fear can set up barriers in daily activities and cause a state of anxiety and even inhibition and/or restriction of these activities ${ }^{(4-5)}$. This can reduce mobility and physical fitness, compromise lower limb muscles and the balance of the older adult, and consequently increase risk of future falls ${ }^{(3-5)}$. This way, the fear of falling may be a predictor of falls and, consequently, of their negative repercussions for the older adult, including demands for individualized care ${ }^{(4,6)}$. As a result, there may be a greater need to use health services, resulting in higher expenses considering the cost of long hospitalizations, medical interventions and medication, among other expenses ${ }^{(2,7)}$.

The "fear of falling" problem has been a major concern not only for the older adult, but also for families and health care providers, considering it can lead to greater use of health services $^{(2-3)}$. The consequences of the fear of falling go through the clinical, psychological, social and epidemiological spheres, and should receive special attention, since the ramifications of the consequences are important for the health, well-being and quality of life (QoL) of the older adult ${ }^{(8)}$.

Based on the identification of the factors associated with the fear of falling in the older adult, it is possible to get an overview that can help in the development of actions aimed not only at the target audience but also actions involving health professionals who deal with the older adult, their relatives and caregivers ${ }^{(8-9)}$. The relevance of the study is based on the premise that knowledge about the factors associated with fear of falls is crucial, since falls of the older adult are an important public health problem and one of the main causes of mental health and QoL impairment in this population ${ }^{(1)}$. Thus, the present study aimed to identify the factors associated with the fear of falling in older adult living at home.

\section{METHOD}

A cross-sectional and probabilistic sampling research was conducted with older adult people aged 60 years or older enrolled in two of the 12 Family Health Strategies (FHS) from a city located in the southern Minas Gerais State, Brazil. The choice for the FHS was made by convenience. The two FHS were chosen because of the familiarity of the institutions with the research team. In 2010, this city had
90,658 inhabitants, with 11,397 (12.57\%) people aged 60 and over. FHS1 $(n=456)$ and FHS2 $(n=444)$ had a total of 7,128 registered people, of which 900 (12.62\%) were older adult. Data was collected between June and August 2012 by two trained members of the research team.

The sample was calculated based on a finite population ${ }^{(10)}$ of 900 older adult people and at least a $90.5 \%$ fear of falling in one of the 16 FES-I-Brazil activities on the study carried out with older adult people from Diamantina, $\mathrm{MG}^{(11)}$; we adopted a sampling error of $\pm 5 \%$ and a $95 \%$ confidence interval $(\alpha=1.96)$. Thus, the minimum sample required for this study was 136 older adults. The numbers of the records of each older adult enrolled in the two FHS were used to draw $50 \%$ of the sample $(n=68)$ in each FHS. For inclusion in the sample, the participants met the following criteria: age $\geq 60$ years, be registered and live within the area covered by one of the FHS that were scenarios of this study. The exclusion criterion adopted was the bedridden older adult.

For this study, a sociodemographic and health household questionnaire was conducted, consisting of the explanatory variables: age; gender; level of education; marital status; chronic disease; daily use of medication; number of falls; time of the last fall; use of glasses; difficulty seeing even with the use of glasses; necessity of walking aid and self-assessment of health status. The Falls Efficacy Scale International scale was used to evaluate the outcome: concern about the possibility of falling. This scale was validated for the Brazilian population (FEI-I-BRAZIL) in $2010^{(12)}$. It has excellent psychometric properties and has been validated in several countries. For Brazil's validation, the internal consistency measured with Cronbach's alpha presented excellent psychometric properties $(\alpha=0.96)$. Through this scale, “it's possible to investigate the concern about the possibility of falling in 16 distinct daily activities, scored on a Likert scale from 1 to 4 , with a score that can vary from 16 (no concern) to 64 (extreme concern). The items evaluated cover tasks related to postural control, associated with a higher level of difficulty, and other basic, instrumental and socialization tasks, which involve less physical demand"(12). Regarding the interpretation of the FES-I-Brazil scale, those responsible for validation in Brazil conclude that the total score is the best element to evaluate the concern about falling ${ }^{(12)}$. The cut-off score used indicate a score of 16 to 22 as low concern and from 23 to 64 as high concern about falling ${ }^{(13)}$.

The data was managed by the Statistical Package for the Social Sciences - SPSS ${ }^{\circledR}$ version 21. To describe the sociodemographic characteristics, and the FES-I-Brazil Scale, descriptive statistics were used. The Kolmogorov-Smirnov test with Lilliefors correction demonstrated normal distribution of the FES-I-Brazil scale ( $\mathrm{p}=0.105)$. Simple Linear Regression (SLR) and Multiple Linear Regression (MLR) ${ }^{(14)}$ were used to identify the factors associated with the fear of falling through the FES-I-Brazil scale (dependent variable). The MLR models were constructed using the stepwise selection technique, starting from the model in which all $\mathrm{p} \geq$ 0.05 variables are excluded. Using two models, it was possible to determine which independent variables were associated with fear of falling among the older adult in this study. The 
Generalized Linear Models (GLM) ${ }^{(15)}$ were used in order to test the mean differences of the FES-I-Brazil among the subgroups of statistically significant MLR covariates defined by number of falls (never, once, twice); gender (male, female); age (60 to 69, 70 or more) and health self-assessment (good, regular). The $\mathrm{F}$ test and the degrees of freedom (d.f.) were used to describe the GLM univariate analysis. The significance level adopted was $5 \%$, with a $95 \%$ confidence interval $(95 \% \mathrm{CI})$.

The study was conducted in accordance with the guidelines and regulatory norms of the Resolution 466/2012 of the National Health Council/Ministry of Health, on Research Involving Human Beings and approved by the Research Ethics Committee under decision number 50521, July $4^{\text {th }}, 2012$. The objectives of the research were clarified and all the participants signed an Informed Consent Form.

\section{RESULTS}

A total of 188 older adult people were approached, eight of whom refused to participate in the study, three were visitors and did not live in the perimeters of the selected FHS, two had psychological conditions of anxiety/sadness and five were bedridden or were wheelchair users. At the end of data collection, 170 older adult people participated in this research, 85 older adult from each FHS (Table 1).

Table 1 - Characteristics of the older adult - Itajubá, Minas Gerais, Brazil, 2012

\begin{tabular}{|c|c|c|}
\hline Variables & & n (\%) \\
\hline \multirow{2}{*}{ Age } & 60 to 69 & $97(57.1)$ \\
\hline & 70 or more & $73(42.9)$ \\
\hline \multirow{2}{*}{ Gender } & Male & $55(32.4)$ \\
\hline & Female & $115(67.6)$ \\
\hline \multirow{3}{*}{ Education } & Never studied & $26(15.3)$ \\
\hline & $<8$ years & $128(75.3)$ \\
\hline & $\geq 8$ years & $16(9.4)$ \\
\hline \multirow{2}{*}{ Marital status } & With a partner & $92(54.1)$ \\
\hline & No partner & $78(45.9)$ \\
\hline \multirow{2}{*}{ Chronic disease } & Yes & $132(77.6)$ \\
\hline & No & $38(22.4)$ \\
\hline \multirow{2}{*}{ Daily medication } & Yes & $141(82.9)$ \\
\hline & No & $29(17.1)$ \\
\hline \multirow{3}{*}{ Number of falls } & Never fell & $40(23.5)$ \\
\hline & Once & $34(20.0)$ \\
\hline & Twice & $96(56.5)$ \\
\hline \multirow{2}{*}{ Time of the last fall } & $<1$ year & $60(46.1)$ \\
\hline & $\geq 1$ year & $70(53.9)$ \\
\hline \multirow{3}{*}{ Wear glasses } & Yes & $61(35.9)$ \\
\hline & No & $61(35.9)$ \\
\hline & Sometimes & $48(28.2)$ \\
\hline \multirow{2}{*}{$\begin{array}{l}\text { Difficulty seeing even with } \\
\text { glasses }\end{array}$} & Yes & $95(55.5)$ \\
\hline & No & $75(44.1)$ \\
\hline \multirow{3}{*}{ Walking aid } & Yes & $21(12.4)$ \\
\hline & No & $146(85.9)$ \\
\hline & Sometimes & $3(1.8)$ \\
\hline \multirow{2}{*}{ Health self-assessment } & Good & $119(70.0)$ \\
\hline & Regular & $51(30.0)$ \\
\hline
\end{tabular}

The majority (57.1\%) were between 60 and 69 years old, $67.6 \%$ were female and $54.1 \%$ of the older adult reported having a partner. Approximately $78.0 \%$ reported having at least one chronic disease and $83 \%$ had daily use of at least one medication. Regarding the history of falls, $76.5 \%$ had had at least one fall and $46.1 \%$ had a fall in the last year. The proportion among the older adult who wore glasses and the ones who did not was the same (35.9\%), and the majority (55.5\%) had difficulty seeing, even with glasses. Approximately, $86 \%$ of the older adult did not use walking aids. Regarding the self-assessment of health status, $70.0 \%$ of the older adult reported that their health was good.

The fear of the possibility of falling assessed by the FES-I Brazil Scale presented mean of 29.5. ( $\mathrm{SD}=10.2 ; 95.0 \%$ confidence interval $=28.0-31.1)$. When rating this fear, the results showed that $66.5 \%(n=113)$ of the older adult presented a score between 23 and 64 in the FES-I Brazil Scale, which represents a high concern about falling, and $33.5 \%(n=57)$ of the older adult had low concern about falling, with a score between 16 and 22 .

Table 2 presents two models of Linear Regression used to evaluate the factors associated with the fear of falling among the older adult in the community. In the first SLR model, it is observed that only the variable number of previous falls explained $21.0 \%$ of the variance of fear of falling $(B=5.6$; $\mathrm{p}<0.001)$. In the final MLR model, the number of previous falls $(B=3.3 ; p<0.001)$, plus gender $(B=-7.0 ; p<0.003)$, age $(B=0.2 ; p<0.001)$ and health self-assessment $(B=-3.7$; $\mathrm{p}=0.001$ ) explained $37.0 \%$ of the variance of fear of falling.

Table 2 - Results of simple and multiple linear regression for the fear of falling in older adult in the FES-I-Brazil Scale - Itajubá, Minas Gerais, Brazil, 2012

\begin{tabular}{lcccc}
\hline Models & Variables & B $(\mathbf{9 5} \% \mathbf{C I})$ & P Value & Adjusted R \\
\hline $\begin{array}{l}1^{\text {st }} \text { model } \\
\text { FES-I-Brazil }\end{array}$ & Number of falls & $5.6(3.9 ; 7.3)$ & $<0.001$ & 0.21 \\
\hline & Number of falls & $3.3(1.6 ; 4.9)$ & $<0.001$ & \\
$\begin{array}{l}\text { Final model } \\
\text { FES-I-Brazil }\end{array}$ & $\begin{array}{c}\text { Gender } \\
\text { Age }\end{array}$ & $-7.0(-9.7 ;-4.2)$ & 0.003 & \\
& $\begin{array}{c}\text { Health self- } \\
\text { assessment }\end{array}$ & $-3.7(-6.0 ; 1.1)$ & 0.001 & \\
\hline
\end{tabular}

a: Used in the Generalized Linear Models; B: Beta coefficient is the estimate of the increase or decrease of the dependent variable for each 1-point increase of the independent variable; CI: 95\% Confidence Interval.

GLMs (Table 3) were used to explore the mean difference between the covariates associated with the fear of falling among the older adult. The fear of falling presented a statistically significant difference between the number of previous falls: $(\mathrm{F}=11.1$; d.f. $=2, ; \mathrm{p}<0.001)$; gender: $(\mathrm{F}=19.5$; d.f. $=1 ; p<0.001)$, age: $(F=4.2 ;$ d.f. $=1 ; p<0.001)$ and health self-assessment: $(F=9.2$; d.f. $=1 ; p=0.003)$.

Regarding the number of previous falls, it was identified that there was no statistically significant difference between the older adult who had never fell and the older adult who had fell only once (mean difference $=-2.9 ; p=0.4)$. But a difference in the fear of falling was observed among the older adult who had never fell and the older adult who had fell twice (mean difference $=-7.7 ; \mathrm{p}<0.001$ ). When comparing 
the older adults who fell once with those who fell twice, the difference in fear of falling was lower and statistically significant $($ mean difference $=-4.7 ; \mathrm{p}=0.021)$. Older women presented greater fear of falling than older men (mean difference $=-8.0 ; \mathrm{p}<0.001)$. The age difference was also a factor that presented discrepancy in the fear of falling. Younger, 60-69 year-olds were less fearful of falling than older adults aged 70 or over (mean difference $=-4.6 ; \mathrm{p}=0.042$ ). Older adult patients with worse health self-assessment were more fearful of falling than older adults with better self-assessment (mean difference $=-7.8 ; \mathrm{p}=0.003$ (Table 3).

Table 3 - Mean difference FES-I-Brazil Scale - Itajubá, Minas Gerais, Brazil, 2012

\begin{tabular}{|c|c|c|c|c|}
\hline \multicolumn{2}{|l|}{ Variables } & Mean difference & $95 \% \mathrm{Cl}$ & P - Value \\
\hline \multicolumn{5}{|c|}{ Number of falls } \\
\hline Never & Once & -2.9 & $-7.7 ; 1.8$ & 0.408 \\
\hline Never & Twice & -7.7 & $-11.8 ;-3.6$ & $<0.001$ \\
\hline Once & Twice & -4.7 & $-8.9 ; 0.5$ & 0.021 \\
\hline Gender & $\begin{array}{c}\text { Male } \\
\text { Female }\end{array}$ & -8.0 & $-9.1 ;-3.4$ & $<0.001$ \\
\hline $\begin{array}{l}\text { Age } \\
\text { (years old) }\end{array}$ & $\begin{array}{c}60 \text { to } 69 \\
70 \text { or more }\end{array}$ & -4.6 & $-5.3 ; 0.1$ & 0.042 \\
\hline $\begin{array}{l}\text { Health self- } \\
\text { assessment }\end{array}$ & $\begin{array}{l}\text { Good } \\
\text { Regular }\end{array}$ & -7.8 & $-8.8 ;-2.4$ & 0.003 \\
\hline
\end{tabular}

Note: Mean difference; SD: standard deviation; CI: confidence interval.

\section{DISCUSSION}

The present study investigated the factors associated with fear of falling among older adult people living at home. The majority of these older adults (67.0\%) had a high fear of falling. The factors associated with fear of falling were: higher number of falls; women; worse health self-assessment and age, especially for those above 70 years.

A higher number of falls was the main factor that explained the fear of falling among the older adult who lived in their own house. Older adults who fell twice were more afraid of falling than older people who had never fell or had fell once. It is noteworthy that no difference in the fear of falling was found between older adults who fell once and those who had never fell. Any older adult person with a history of falls, with or without injury, is more likely to trigger a fear of falling ${ }^{(11,13)}$. Recurring falls among the older adult has been highlighted as a relevant factor for the development of fear of falling ${ }^{(16-17)}$. Fear, in most cases, is related to the possibility of fractures, hospitalization and compromising autonomy of the older adult ${ }^{(13,17)}$. This fear can trigger changes in the behavior of the older adult, such as restrictions of basic daily and instrumental activities and reduction of physical fitness, which lead to cardiovascular risks and musculoskeletal disorders. In addition, it may increase the risk of falls ${ }^{(4,18)}$ and compromise the QoL of the older adult ${ }^{(6)}$.

Falls and fear of falling are mutually associated, since the older adult presenting an outcome have a high risk of developing the other ${ }^{(6)}$. In the present study, no significant difference was identified between the fear of falling among the older adult who fell once and those who never fell. In previous studies, a statistically significant difference in the fear of falling among older adult people who never fell and who fell once was detected ${ }^{(11)}$. It is believed that this finding may be associated with the severity of the fall. Older adults who suffered a fall with complications, such as fractures or injuries, are more afraid of falling than older adult people who did not suffer complications ${ }^{(6,8)}$. This study did not investigate the outcome fracture/lesions, which may make it difficult to make some inferences with the present findings.

An influence of the female gender on the fear of falling was observed. Older adult women were more likely to fall than older adult men ${ }^{(19)}$. The fear of falling among older adult women was associated with reduced physical activity ${ }^{(19)}$; obesity $^{(20-21)}$; impairment of activities of daily living (ADLs) ${ }^{(19)}$; social isolation ${ }^{(4)}$; higher depressive symptoms ${ }^{(20,22)}$; higher probability of future falls ${ }^{(23)}$. The fear of falling among older adult women is influenced by a number of factors peculiar to gender, such as a higher prevalence of chronic non-communicable diseases (NCDs) and musculoskeletal frailty ${ }^{(23)}$; low bone density after menopause and greater and more rapid loss of muscle mass, due to the hormonal decrease ${ }^{(24)}$. It is also believed that the higher frequency of household tasks can influence this fear ${ }^{(3)}$. Older adult women also have more difficulty engaging in physical activities of muscle strengthening ${ }^{(25)}$. Another factor that should be highlighted is that even though women recognize health risks more easily, men are more resistant to accepting these risks ${ }^{(26)}$.

Older people who assessed their health status as "regular" were more afraid of falling than the older adult with "good" health self-assessment. A worst health status among the older adult has been associated with greater fear of falling in international studies, such as studies in The United States of America $^{(27)}$, England ${ }^{(28)}, \mathrm{Nigeria}^{(4)}$, and also Brazil ${ }^{(7)}$. To the World Health Organization ${ }^{(4)}$, in addition to NCDs, physical and cognitive decline, physical frailty, affective impairment, and depression may exacerbate the fear and risk of falling among the older adult. This study corroborates the need to detect older adult people vulnerable to this fear, with the purpose of elaborating preventive measures against the increase of the fear of falling to contribute to the reduction of the fear of falling and the number of falls among these older adults.

Age was another factor associated with fear of falling. 70 years old or older adults were more fearful of falling than younger older adult people (60-69 years). The older adult usually present with advancing age a decline in physical and mental functioning, as well as an increase in physical frailty and in the number of $\mathrm{NCDs}^{(29)}$. This set of alterations affects the older and contributes to the greater fear of falling among older individuals ${ }^{(19)}$. A population-based study with 9,033 South Korean, aged over 65, found that older people over 75 years of age are more likely to have fear of falling than younger older adult ${ }^{(30)}$. A higher age was also associated with a greater fear of falling in other international studies ${ }^{(28)}$. In relation to the published national literature, this study is regarded as different from the others because it identifies 
that with the advancement of age, the fear of falling in older adult people living at home increases.

The present study has some limitations. During the research conducted in their homes, it was not investigated whether, after the fall, there were fractures/lesions. It is believed that this questioning could help explain why there was no association of the fear of falling among older adult who had never fell and those who had fell once, which opens a gap for future studies. Other limitations were the reduced number of older adult people aged 80 years or older, which made it difficult to use this category in the results and analysis, and the use of only two categories to assess the perception of the health status of the older adult.

\section{CONCLUSION}

This study showed that the older adult who have already fallen twice, female, with worse health self-assessment, and over 70 years of age were more afraid of falling. In terms of recommendations for practice, the findings reinforce the need to assess the fear of falling among older adult people living at home. This assessment does not imply high costs, it is uncomplicated and can be carried out by members of the multi-professional team of the FHS or Basic Health Units (BHU), which are closer to the community. Supervised physical exercises for strengthening upper and lower limb muscles and developing balance should be provided. Group and individual educational activities are important because they aim to understand the risks of falls and provide the idea that the fear of falling is controllable. The supervision of modifiable risk factors in the older adult households should be carried out by the multi-professional team of the FHS or the BHU, to reduce the possibility of falling. The associated factors found in this study can contribute to the elaboration of preventive actions to reduce the fear of falling and the possible consequences of this fear in ADL, physical and mental health, socialization and in the QoL of the older adult, besides impacting on the costs and organization of health systems and services.

Longitudinal studies in larger samples with a multifactorial approach should be carried out to identify the possible predictive factors of the fear of falling from older adult living at home.

\section{RESUMO}

Objetivo: Identificar os fatores associados ao medo de cair em idosos residentes no domicílio. Métodos: Estudo transversal com amostragem probabilística de idosos cadastrados em duas Estratégias Saúde da Família (ESF). O medo de cair foi avaliado pela versão brasileira da escala Falls Efficacy Scale International e por um inquérito domiciliar que continha as variáveis explicativas. A Regressão Linear Múltipla por meio da técnica stepwise selection e os Modelos Lineares Generalizados foram utilizados nas análises estatísticas. Resultados: Participaram da pesquisa 170 idosos, 85 de cada ESF. A maioria (57,1\%) tinha entre 60 e 69 anos de idade; 67,6\% eram do sexo feminino; $46,1 \%$ tiveram queda no último ano. A maioria dos idosos $(66,5 \%)$ tinha elevado medo de cair. No modelo final de regressão multivariada, identificou-se que maior número de quedas anteriores, sexo feminino, idade mais avançada, e pior autoavaliação de saúde explicaram 37\% do medo de cair entre os idosos. Conclusão: Os achados reforçam a necessidade da avaliação do medo de cair entre os idosos que residem no próprio domicílio, assim como o desenvolvimento e a utilização de estratégias pelos profissionais voltadas para os fatores modificáveis, de modo a reduzir as quedas e melhorar o estado de saúde, o que pode contribuir para a diminuição do medo de cair entre os idosos.

\section{DESCRITORES}

Idoso; Acidentes por Quedas; Medo; Enfermagem Geriátrica; Estratégia Saúde da Família; Estudos Transversais.

\section{RESUMEN}

Objetivo: Identificar los factores asociados con el miedo de caer en ancianos residentes en su domicilio. Métodos: Estudio transversal con muestreo probabilístico de ancianos registrados en dos Estrategias Salud de la Familia (ESF). El miedo de caer fue evaluado por la versión brasileña de la escala Falls Efficacy Scale International y por una encuesta domiciliaria que contenía las variables explicativas. La Regresión Lineal Múltiple mediante la técnica stepwise selection y los Modelos Lineales Generalizados fueron utilizados en los análisis estadísticos. Resultados: Participaron en la investigación 170 ancianos, 85 de cada ESF. La mayoría (57,1\%) tenía entre 60 y 69 años de edad; el 67,6\% eran del sexo femenino; el 46,1 \% sufrieron caída el último año. La mayoría de los ancianos (66,5\%) tenía elevado miedo de caer. En el modelo final de regresión multivariada, se identificó que mayor número de caídas anteriores, sexo femenino, edad más avanzada y peor autoevaluación de salud explicaron el 37\% del miedo de caer entre los ancianos. Conclusión: Los hallazgos refuerzan la necesidad de la evaluación del miedo de caer entre los ancianos que residen en su propio domicilio, así como el desarrollo y la utilización de estrategias por los profesionales dirigidos a los factores cambiables, a fin de reducir las caídas y mejorar el estado de salud, lo que puede contribuir para la reducción del miedo de caer entre los ancianos.

\section{DESCRIPTORES}

Anciano; Accidentes por Caídas; Miedo; Enfermería Geriátrica; Estrategia de Salud Familiar; Estudios Transversales.

\section{REFERENCES}

1. Heslop KR, Wynaden DG. Impact of falls on mental health outcomes for older adult mental health patients: an Australian study. Int J Ment Health Nurs. 2016;25(1):3-11.

2. Center for Disease Control and Prevention. Important facts about falls [Internet]. 2015 [cited 2016 Jan 29]. Available from: http://www. cdc.gov/homeandrecreationalsafety/falls/adultfalls.html. 
3. Ayoubi F, Launay C, Annweiler C, Beauchet O. Fear of falling and gait variability in older adults: a systematic review and meta-analysis. J Am Med Dir Assoc. 2015;16(1):14-9.

4. World Health Organization. WHO Global report on falls prevention in older age [Internet]. Geneva: WHO; 2007 [cited 2016 Jan 14]. Available from: http://www.who.int/ageing/publications/Falls_prevention7March.pdf

5. Shirooka H, Nishiguchi S, Fukutani N, Tashiro Y, Nozaki Y, Hirata H, et al. Cognitive impairment is associated with the absence of fear of falling in community-dwelling frail older adults. Geriatr Gerontol Int. 2016 Jan 21. [Epub ahead of print]

6. Akosile CO, Anukam GO, Johnson OE, Fabunmi AA, Okoye EC, Iheukwumere N, et al. Fear of falling and quality of life of apparentlyhealthy elderly individuals from a Nigerian population. J Cross Cult Gerontol. 2014;29(2):201-9.

7. Antes DL, Schneider IJC, Benedetti TRB, D'Orsi E. Medo de queda recorrente e fatores associados em idosos de Florianópolis, Santa Catarina, Brasil. Cad Saúde Pública. [Internet]. 2013 [citado 2016 jan. 04];29(4):758-68. Disponível em: http://www.scielo.br/pdf/csp/ v29n4/13.pdf.

8. Lach HW, Parsons JL. Impact of fear of falling in long term care: an integrative review. J Am Med Dir Assoc. 2013;14(8):573-7.

9. Akin S, Mazicioglu MM, Mucuk S, Gocer S, Safak ED, Arguvanli S, et al. The prevalence of frailty and related factors in communitydwelling Turkish elderly according to modified Fried Frailty Index and FRAIL scales. Aging Clin Exp Res. 2015;27(5):703-9.

10. Fontelles MJ, Simões MG, Almeida JC, Fontelles RGS. Metodologia da pesquisa: diretrizes para o cálculo do tamanho da amostra. Rev Para Med. 2010;24(2):57-64.

11. Lopes KT, Costa DF, Santos LF, Castro DP, Bastone AC. Prevalence of fear of falling among a population of older adults and its correlation with mobility, dynamic balance, risk and history of falls. Rev Bras Fisioter [Internet]. 2010 [cited 2016 Feb 04];13(3): 223-9. Available from: http://www.scielo.br/pdf/rbfis/v13n3/en_aop024_09.pdf

12. Camargos FFO, Dias RC, Dias JMD, Freire MTF. Cross-cultural adaptation and evaluation of the psychometric properties of the Falls Efficacy Scale - International Among Elderly Brazilians (FES-I-BRAZIL). Rev Bras Fisioter [Internet]. 2010 [cited 2016 Feb 15];14(3):237-43. Available from: http://www.scielo.br/pdf/rbfis/v14n3/en_10.pdf

13. Delbaere K, Close JC, Heim J, Sachdev PS, Brodaty H, Slavin MJ, et al. A multifactorial approach to understanding fall risk in older people. J Am Geriatr Soc. 2010;58(9):1679-85.

14. Alexopoulos EC. Introduction to multivariate regression analysis. Hippokratia. [Internet]. 2010 [cited 2016 July 11];14 Suppl 1):23-8. Available from: http://www.ncbi.nlm.nih.gov/pmc/articles/PMC3049417/

15. Taylor A. Using the GLM procedure in SPSS. Macquarie: Macquarie University; 2011.

16. Bryant MS, Rintala DH, Hou JG, Protas EJ. Influence of fear of falling on gait and balance in Parkinson's disease. Disabil Rehabil. 2014;36(9):744-8

17. Mane AB, Sanjana T, Patil PR, Sriniwas T. Prevalence and correlates of fear of falling among elderly population in urban area of Karnataka, India. J Midlife Health. [Internet]. 2014 [cited 2016 Feb 15];5(3):150-5. Available from: http://www.ncbi.nlm.nih.gov/pmc/articles/ PMC4195189/

18. Mazumder R, Lambert WE, Nguyen T, Bourdette DN, Cameron MH. Fear of falling is associated with recurrent falls in people with multiple sclerosis. Int J MS Care. [Internet]. 2015 [cited 2016 Feb 15];17(4):164-70. Available from: https://www.ncbi.nlm.nih.gov/pmc/articles/ PMC4542711/

19. Centers for Disease Control and Prevention; National Center for Injury Prevention and Control. Preventing falls: a guide to implementing effective community-based fall prevention programs [Internet]. Atlanta: CDC; 2015 [cited 2016 Jan 10]. Available from: http://www.cdc. gov/homeandrecreationalsafety/pdf/falls/fallpreventionguide-2015-a.pdf

20. Pohl P, Sandlund M, Ahlgren C, Bergvall-Kåreborn C, Lundin-Olsson L, Wikman AM. Fall risk awareness and safety precautions taken by older community-dwelling women and men: a qualitative study using focus group discussions. PLoS One. 2015;10(3):e0119630.

21. Jeon B. The effects of obesity on fall efficacy in elderly people. J Phys Ther Sci [Internet]. 2013 [cited 2016 July 10];25(11):1485-9. Available from: https://www.ncbi.nlm.nih.gov/pmc/articles/PMC3881484/

22. White UE, Black AA, Wood JM, Delbaere K. Fear of falling in vision impairment. Optom Vis Sci. 2015;92(6):730-5.

23. Ambrose AF, Cruz L, Paul G. Falls and fractures: a systematic approach to screening and prevention. Maturitas. 2015;82(1):85-93.

24. Hita-Contreras F, Martínez-Amat A, Lomas-Vega R, Álvarez P, Aránega A, Martínez-López E, et al. Predictive value of stabilometry and fear of falling on falls in postmenopausal women. Climacteric. 2013;16(5):584-9.

25. Visschedijk JHM, Caljouw MAA, Bakkers E, van Balen R, Achterberg WP. Longitudinal follow-up study on fear of falling during and after rehabilitation in skilled nursing facilities. BMC Geriatrics [Internet]. 2015 [cited 2016 July 10];15:161. Available from: https://www.ncbi. nlm.nih.gov/pmc/articles/PMC4670507/

26. Knauth DR, Couto MT, Figueiredo WS. The standpoint of professionals on the presence and demands of men on the healthcare services: perspectives for the analysis of the implementation of the Comprehensive Healthcare Policy for Men. Ciênc Saúde Coletiva [Internet]. 2012 [cited 2016 Jan 15];17(10):2617-26. Available from: http://www.scielo.br/pdf/csc/v17n10/en_11.pdf

27. Bryant MS, Rintala DH, Hou JG, Protas EJ. Relationship of falls and fear of falling to activity limitations and physical inactivity in Parkinson's disease. J Aging Phys Act. 2015;23(2):187-93.

28. Denkinger MD, Lukas A, Nikolaus T, Hauer K. Factors associated with fear of falling and associated activity restriction in communitydwelling older adults: a systematic review. Am J Geriatr Psychiatry. 2015;23(1):72-86.

29. Cho H, Seol SJ, Yoon DH, Kim MJ, Choi BY, Kim T. Disparity in the Fear of Falling Between Urban and Rural Residents in Relation With Socio-economic Variables, Health Issues, and Functional Independency. Ann Rehabil Med. 2013;37(6):848-61.

30. Kim S, So WY. Prevalence and correlates of fear of falling in Korean community-dwelling elderly subjects. Exp Gerontol. 2013;48(11):1323-8. 